\title{
Berlin Initiative Study 1 equation and HUGE formula for more accurate estimation of kidney function in elderly
}

\author{
Marija Matašin ${ }^{* 1}$, Viktor Domislović ${ }^{2}$ Mirjana Fuček ${ }^{3}$, Lana Gellineo ${ }^{1}$, Ana \\ Jelaković ${ }^{1}, \check{Z}$ ivka Dika $^{1,4}$, Bojan Jelaković ${ }^{* 1,4}$ \\ Department of Nephrology, Hypertension, Dialysis and Transplantation, University Hospital Centre Zagreb, Zagreb, Croatia \\ Department of Gastroenterology and Hepatology, University Hospital Centre Zagreb, Zagreb, Croatia \\ 3 Department of Laboratory Diagnostics, University Hospital Centre Zagreb, Zagreb, Croatia \\ ${ }^{4}$ University of Zagreb School of Medicine, Zagreb, Croatia
}

OPEN ACCESS

Correspondence: Marija Matašin matasin.marija@gmail.com orcid.org/0000-0002-8640-748X

This article was submitted to RAD CASA - Medical Sciences as the original article

Conflict of Interest Statement: The authors declare that the research was conducted in the absence of any commercial or financial relationships that could be construed as a potential

Received: 10 May 2021 Accepted: 18 May 2021 Published: 15 June 2021

Citation:

Matašin $M$, Domislović $V$, Fuček M, Gellineo L, Jelaković A, Dika Ž, Jelaković B. Berlin Initiative Study 1 equation and HUGE formula for more in elderly

RAD CASA - Medical Sciences. $547=54-55(2021): 24-31$ DOI: https://dx.doi.org/10.21857/ ydkx $2 \mathrm{cw} 8 \mathrm{k} 9$

Copyright (C) 2021 Matašin M, Domislović $V$, Fuček M, Gellineo $L$, Jelaković A, Dika Ž, Jelaković B. This is an open-access article distributed is an open-access article distributed under the terms of the Creative Comons Attribution License (CC BY). The use, distribution or reproduction in other forums is permitted, provided the original author(s) and the copyright owners(s) are credited and that the original publication in this journal is cited, in accordance whit accepted dacemic practice. No use, distribution or reproduction is permitted which does not comply with these terms.

\section{ABSTRACT:}

Introduction: Chronic kidney disease (CKD) is one of the leading public health problems and a significant concern in the elderly population. Assessment of renal function in elderly is difficult due to the physiological decline of GFR with aging. Furthermore, recommended eGFR CKD EPI equation has not been validated in the elderly. Our aim was to analyze in a group of subjects older than 70 years the differences in CKD prevalence and eGFR stages using CKD EPI and BIS1 equations (validated in elderly) and to distinguish the presence normal kidney aging from CKD using the HUGE equation. Materials and Methods: This cross-sectional observational study included 383 subjects older than 70 years who were part of ENAH study $(\mathrm{N}=2193)$. CKD was defined as an eGFR $<60 \mathrm{~mL} / \mathrm{min} / 1.73 \mathrm{~m}^{2}$; CKD stages were classified according to the KDIGO guidelines. The eGFR was calculated using CKD EPI and BIS1 equation. The HUGE equation was calculated in subset of 75 subjects.

Results: The average age of the study population was 75 years. BIS1 classified $22.7 \%$ subjects more to a GFR $<60 \mathrm{~mL} / \mathrm{min} / 1.73 \mathrm{~m}^{2}$ than CKD EPI. A systematic difference was found between the equations, with BIS1 mean value being lower for $8.0 \mathrm{~mL} / \mathrm{min}$ than that of CKD EPI. Less falsely CKD $(8.6 \%$ subjects) i.e. more normal kidney aging was detected using BIS1 instead of CKD EPI equation. Conclusions: The prevalence of CKD was higher with BIS1 than with CKD EPI equation i.e. CKD EPI underestimated CKD prevalence in elderly. More accurate diagnosis of CKD, and better determination of CKD prevalence in subjects older than 70 years could be obtained using BIS1 equation with addition of HUGE equation.

Keywords: Berlin Initiative Study equation, CKD EPI equations, chronic kidney disease, estimated glomerular filtration rate, HUGE, elderly

\section{SAŽETAK:}

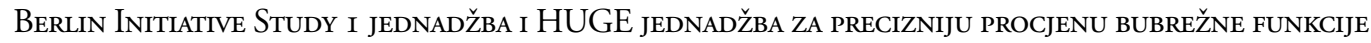
u STARIJIH

Uvod: Kronična bubrežna bolest $(\mathrm{KBB})$ jedan je od vodećih javnozdravstvenih problema i značajan problem kod starijih osoba. Procjena funkcije bubrega kod starijih osoba otežana je zbog fiziološkoga pada GFR. Nadalje, preporučena eGFR CKD EPI jednadžba nije validirana u starijih osoba. Cilj naše studije je bio analizirati razlike u prevalenciji KBB u skupini ispitanika starijih od 70 godina koristeći CKD EPI i BIS1 jednadžbe koja je validirana u starijih, te utvrditi razlike između normalnog bubrežnog starenja i KBB koristeći HUGE jednadžbu.

Materijali i metode: U ovu presječnu opservacijsku studiju uključeno je 383 ispitanika starijih od 70 godina koji su bili dio ENAH studije $(\mathrm{N}=2193)$. KBB je definirana kao eGFR $<60 \mathrm{~mL} / \mathrm{min} / 1,73 \mathrm{~m}^{2}$. 
Stadiji KBB određeni su prema KDIGO smjernicama. Vrijednosti eGFR određene su koristeći CKD EPI i BIS1 jednadžbu. HUGE jednadžba izračunata je u podskupini od 75 ispitanika.

Rezultati: Prosječna starost ispitanika bila je 75 godina. BIS1 klasificirala je 22,7\% ispitanika više u skupinu s vrijednosti eGFR $<60 \mathrm{~mL} / \mathrm{min} / 1,73 \mathrm{~m}^{2}$ od CKD EPI. Utvrđena je sistemska razlika između jednadžbi, pri čemu je srednja vrijednosti BIS1 bila manja za $8,0 \mathrm{~mL} / \mathrm{min}$ od vrijednosti CKD EPI. Manje lažno dijagnosticirane KBB (8,6\% ispitanika) tj. normalno bubrežno starenje otkriveno je koristeći BIS1 umjesto CKD EPI jednadžbu.

Zaključci: Prevalencija KBB bila je veća koristeći BIS1 nego CKD EPI jednadžbu, tj. CKD EPI podcijenila je prevalenciju KBB u starijih osoba. Koristeći BIS1 uz dodatak HUGE formule mogla bi se preciznije dijagnosticirati i točnije odrediti prevalencija KBB u starijih od 70 godina.

KLJUČNE RIJEČI: BIS1, CKD EPI, kronična bubrežna bolest, procjena brzine glomerularne filtracije, HUGE, starije osobe

\section{INTRODUCTION:}

Chronic kidney disease (CKD) is one of the leading public health problems and a significant concern in the elderly population, especially with increasing incidence of its leading causes and risk factors, such as hypertension, obesity, and diabetes mellitus $1,2,3,4$. The global prevalence of CKD in 2017 was $9.1 \%$, with a record of almost 700 million cases of all-stage CKD ${ }^{1}$. CKD has grown worryingly as an important cause of death, moving from $17^{\text {th }}$ to $12^{\text {th }}$ place in last 30 years ${ }^{1}$. The prevalence of CKD and end-stage-kidney-disease (ESKD) are high among the elderly population and are increasing with aging ${ }^{4,5,6,7}$. CKD is associated with the risk of ESKD, but also is an independent cardiovascular $(\mathrm{CV})$ risk factor, with only one in five patients with CKD experiencing the need for renal replacement therapy while four of five patients die most commonly from CV or cerebrovascular death ${ }^{1,3,4,8}$. Glomerular filtration rate (GFR) was considered the best indicator of global kidney function in health and disease ${ }^{9}$. KDIGO guidelines recommended The Chronic Kidney Disease Epidemiology Collaboration (CKD EPI) equation for routine reporting of estimated GFR (eGFR) in adults. KDIGO recommended an alternative equation if it showed to have higher accuracy compared to the CKD EPI equation ${ }^{9}$. CKD EPI equation has several limitations. Firstly, it was validated on a relatively small number of elderly subjects (older than 70 years) and secondly, it is adjusted to the unique body surface area of 1.73 $\mathrm{m}^{2}{ }^{10}$. Recently, Berlin Initiative Study 1 equation (BIS1) was found to be more appropriate for subjects older than 70 years ${ }^{11}$. It was developed in the year 2012 using data from a German population aged 70 years or older and showed better accuracy than other creatinine-based formulas in elderly subjects ${ }^{11}$. Given the increased prevalence of CKD and its causes in the elderly population, an accurate and precise diagnosis of CKD is of paramount importance. Furthermore, it is difficult to determine the difference between CKD in elderly, i.e. a clinically significant decline in renal function with decline in GFR physiologically caused by aging. In normal aging GFR decline by about 6 to 7 $\mathrm{mL} / \mathrm{min} / 1.73 \mathrm{~m}^{2}$ per decade starting after age 35 to 40 . There- fore, the suitability of a cut-off value of eGFR less than $60 \mathrm{~mL} /$ $\mathrm{min} / 1.73 \mathrm{~m}^{2}$ as the cut-off for CKD in the elderly is debatable 12,13,14. Therefore, the HUGE equation was derived to determine presence of CKD without considering the patient's GFR that which is important in the elderly where reduced eGFR as already mentioned, does not always mean the presence of CKD ${ }^{15}$. Our aim was to analyze in a group of subjects older than 70 years the differences in CKD prevalence and eGFR stages using CKD EPI and BIS1 equations and to distinguish the presence of normal kidney aging from CKD using the HUGE equation.

\section{Materials and Methods}

\section{Patient Data}

This cross-sectional observational study included 383 subjects older than 70 years (136 men and 247 women) from a rural area in the continental part of Croatia who were part of the large cohort from the ENAH study $(\mathrm{N}=2193)$. Subjects were invited to participate and were examined on a door-to-door basis. Exclusion criteria were pregnancy, patients with a terminal illness who were bed-ridden, patients with severe disability or those who had at least one limb amputated or immobilized as well as mentally ill or suffering from dementia.

\section{Methods}

Physicians and trained nurses collected the data through epidemiological questionnaires, medical history, and clinical examination. All study personnel were trained to collect survey and clinical information in a standardized manner. Participants completed an extensive questionnaire, provided a spot urine and fasting blood sample. Weight and height were measured, and the body mass index (BMI) was calculated. Abdominal obesity was defined as waist circumference for males $>102 \mathrm{~cm}$ and for females $>88 \mathrm{~cm}$. Blood pressure (BP) was measured three times on the non-dominant arm by an Omron M6 device as per ESH/ECS guidelines. Hypertension was defined as BP $\geq 140 / 90 \mathrm{mmHg}$ and/or the use of antihypertensive drugs. Diabetes was defined as fasting blood glucose $>7 \mathrm{mmol} / \mathrm{L}$ and/ 
or the use of antidiabetic drugs. CKD was defined as an eGFR $<60 \mathrm{~mL} / \mathrm{min} / 1.73 \mathrm{~m}^{2}$; CKD stages were classified according to the Kidney Disease Improving Global Outcomes guidelines into 5 stages.

Serum creatinine was measured on the Olympus AU 2700 analyzer using the Jaffé kinetic uncompensated method with continuous measurement (Beckman Coulter, California, USA). Calibration was performed using calibrators from the same company that can be monitored by the IDMS method and standard reference material. The eGFR was calculated by creatinine based CKD EPI and BIS1 equations ${ }^{10,11}$. The HUGE equation was calculated in subset of 75 subjects depending on the gender and applying serum urea and hematocrit to the equation. HUGE equation was used to distinguish normal kidney aging from CKD, regardless of the subject's age, serum creatinine or eGFR values ${ }^{15}$. If the value of HUGE equation was $\geq 0$, it meant that subject had $\mathrm{CKD}$, if the value was $<0$, it was a case of normal kidney aging. CKD EPI, BIS1 and HUGE equations are shown below:

\section{REsults}

Characteristics of the study population are shown in Table 1. The study included 383 subjects older than 70 years, $64.49 \%$ of them were female. The average age of the study population was 75 years (72-78). The average BMI of the study population was $27.6 \mathrm{~kg} / \mathrm{m}^{2}$ with higher values obtained in the female gender $\left(28.5 \mathrm{~kg} / \mathrm{m}^{2}\right.$ vs. $\left.26.5 \mathrm{~kg} / \mathrm{m}^{2} ; \mathrm{p}<0.001\right)$, and $38.1 \%$ of the study population had abdominal obesity. BSA values obtained with Moesteller equation were on average $1.82 \mathrm{~m}^{2}$, significantly higher than the value of $1.73 \mathrm{~m}^{2}$, the number included in the CKD EPI equation. Hypertension was present in $89 \%$ of the study population with average values of systolic BP $156.4 \pm 25.6 \mathrm{mmHg}$ and diastolic BP $85.4 \pm 14.1 \mathrm{mmHg}$. Average values of total cholesterol and LDL were slightly above reference values, 5.8 (5.0-6.6) $\mathrm{mmol} / \mathrm{L}$ and 3.5 (2.9-4.2) $\mathrm{mmol} / \mathrm{L}$, respectively. Women were older and more women than men were obese and had been diagnosed with diabetes and hypertension. Albuminuria was found in $14.9 \%$, without any differences between genders.

\begin{tabular}{|c|c|c|c|}
\hline \multirow{5}{*}{ CKD-EPI } & Race and gender & $\begin{array}{l}\text { Serum creatinine } \mu \mathrm{mol} / \mathrm{L} \\
(\mathrm{mg} / \mathrm{dl})\end{array}$ & Equation $\left(\mathrm{ml} / \mathrm{min} / 1.73 \mathrm{~m}^{2}\right)$ \\
\hline & \multirow{2}{*}{ Caucasian women } & $\leq 62(\leq 0.7)$ & $\mathrm{eGFR}=144 \times(\mathrm{Scr} / 0.7)^{-0.329} \times(0.993)^{\text {Age }}$ \\
\hline & & $>62(>0.7)$ & $\mathrm{eGFR}=144 \times(\mathrm{Scr} / 0.7)^{-1.209} \times(0.993)^{\text {Age }}$ \\
\hline & \multirow{2}{*}{ Caucasian men } & $\leq 80(\leq 0.9)$ & $\mathrm{eGFR}=141 \times(\mathrm{Scr} / 0.9)^{-0.411} \times(0.993)^{\text {Age }}$ \\
\hline & & $>80(>0.9)$ & $\mathrm{eGFR}=141 \times(\mathrm{Scr} / 0.9)^{-1.209} \times(0.993)^{\mathrm{Age}}$ \\
\hline BIS 1 & \multicolumn{3}{|c|}{$\mathrm{eGFR}=3736 \times \mathrm{Scr}^{-0.87} \times \mathrm{Age}^{-0.95} \times 0.82$ (if female) } \\
\hline HUGE & \multicolumn{3}{|c|}{$=2.505458-(0.264418 \times$ Hematocrit $)+(0.118100 \times$ Urea $)+(1.383960$ if male $)$} \\
\hline
\end{tabular}

The study was approved by the Ethical Board of School of Medicine University of Zagreb, Croatian National Institute of Public Health and General Hospital 'Dr. Josip Benčević' Slavonski Brod, and all participants gave written informed consent.

\section{STATISTICAL ANALYSIS}

Categorical variables were shown as percentages and continuous variables as means with standard deviation for normally distributed variables or medians with interquartile range $\left(25^{\text {th }}\right.$ and $75^{\text {th }}$ percentiles) for non-normally distributed. Categorical variables were compared using chi-square or Fischer exact test. Continuous variables were compared using independent sample t-test, paired-samples t-test, or Mann-Whitney U-test, depending on the distribution. Differences between equations were analyzed using the chi-square test, kappa inter-rater agreement, and Bland-Altman plot analysis. Statistical significance was set, and statistical analysis was performed at 0.05 using SPSS version 23.0 (IBM Corp., USA).
The prevalence of CKD defined as eGFR $<60 \mathrm{~mL} / \mathrm{min} / 1.73 \mathrm{~m}^{2}$ was significantly higher in the whole study population, men and women, when eGFR was calculated using BIS1 equation instead of CKD EPI equation ( $57.4 \%$ vs. $34.7 \%$; $52.9 \%$ vs. $30.9 \%$; $59.9 \%$ vs. $36.8 \%$, respectively; all $\mathrm{p}<0.001$ ) (Table 2 and Table 3). The agreement between CKD EPI and BIS1 for subjects older than 70 years was moderate, kappa 0.56 (95\% CI 0.49-0.63). BIS1 equation showed a downward reclassification, with lower eGFR using BIS1 for stages 3a and 3b. BIS1 classified 22.7\% subjects more to a GFR $<60 \mathrm{~mL} / \mathrm{min} / 1.73 \mathrm{~m}^{2}$ than CKD EPI. A systematic difference was found between the equations, with BIS1 mean value being lower for $8.0 \mathrm{~mL} / \mathrm{min}$ than that of CKD EPI (95\% limits of agreement: +1.9 to -17.8 ) (Figure 1). The prevalence of CKD and normal kidney aging determined by HUGE is shown in Table 4. Less falsely CKD (8.6\% subjects) i.e. more normal kidney aging was detected using BIS1 instead of CKD EPI equation. However, difference was not statistically significant. When results of HUGE were considered than the true prevalence of CKD was significantly lower for both equations. When 
subjects with normal aging were subtracted $(\mathrm{HUGE}<0)$ the prevalence of CKD was $28.4 \%$ (63.1\%-34.7\%) using BIS equation, and $4.6 \%(30.7 \%-26.1 \%)$ using CKD EPI equation.

\section{DISCUSSION}

In this study, we found significant difference with modest agreement between the CKD EPI equation and the BIS1 equation in elderly subjects. There was a significant difference in classifying subjects in CKD stages using CKD EPI and BIS1 equations. This suggests that in elderly BIS1 equations could be more appropriate than currently recommended CKD EPI equation. This is in line with other studies which evaluated the BIS1 equation in the elderly ${ }^{11,16,17,18}$. A study by Schaeffner et al. on 570 elderly subjects (mean age 78.5 years) found that BIS1 showed higher accuracy and agreement with measured GFR (mGFR) than CKD EPI equation, especially in patients with eGFR $>30 \mathrm{~mL} / \mathrm{min} / 1.73$ $\mathrm{m}^{211}$. Furthermore, in a retrospective analysis by Koppe et al. on 224 Caucasian patients older than 70 years, reported that BIS1 has higher accuracy and precision than the CKD EPI or MDRD equation with the lowest median bias and the highest concordance correlation coefficient compared with mGFR. However, better performance of BIS1 was showed for $\mathrm{mGFR}>30 \mathrm{~mL} /$ $\min / 1.73 \mathrm{~m}^{2}$, while CKD EPI was more accurate for lower values ${ }^{16}$. In our study median eGFR values calculated using the BIS1 equation were lower than that of CKD EPI (58.2 vs. $66.8 \mathrm{~mL}$ / $\mathrm{min} / 1.73 \mathrm{~m}^{2}$, respectively), with lower values observed in women. These results are in line with the results published by Lengnan et al. where BIS1 eGFR values were the lowest in elderly subjects compared to eGFR calculated with CKD EPI, MDRD, and FAS equations ${ }^{17}$. In addition, Polkinghorne et al. performed study on 17762 subjects (mean age 75.1 years) and reported lower eGFR values using BIS1 compared to CKD EPI (mean eGFR 62.7 vs. $\left.73.0 \mathrm{~mL} / \mathrm{min} / 1.73 \mathrm{~m}^{2}\right)^{18}$.

In the study where CKD EPI equation was derived, the percentage of subjects older than 70 years was small (between 3-7\%)

${ }^{10}$. On the other side, the BIS 1 equation has been specifically developed for elderly, where all subjects included in the study were older than 70 years (mean age of study population was 78.5 years ${ }^{11}$. Thus, in this study we included subjects of that age (median age 75 years). In our study BIS 1 equation classified $22.7 \%$ subjects more to have CKD i.e. eGFR $<60 \mathrm{~mL} /$ $\mathrm{min} / 1.73 \mathrm{~m}^{2}$ compared to the CKD EPI equation. This is in line with results published by Tarantini et al. on 7845 subjects older than 70 years, where BIS1 equation classified $20.1 \%$ subjects more to eGFR $<60 \mathrm{~mL} / \mathrm{min} / 1.73 \mathrm{~m}^{2}$ than CKD EPI equation ${ }^{19}$. Similar results were observed in other similar studies such as Polkinghorne et al. (22.34\%), Schaeffner et al. (19.3\%) and Corsonello et al. $(27 \%)^{11,18,20}$. Bland Altman analysis showed mean difference of $8.0 \mathrm{~mL} / \mathrm{min} / 1.73 \mathrm{~m}^{2}$ being lower using BIS1 than CKD EPI (95\% limits of agreement: +1.9 to -17.8$)$. This is also in line with results from other studies. Tarantini et al. found a systematic difference between equations, with the BIS1 mean difference of $8.9 \mathrm{~mL} / \mathrm{min} / 1.73 \mathrm{~m}^{2}$ being lower than CKD EPI (95\% limits of agreement: +3.4 to -21.3$){ }^{19}$. Furthermore, multicentric observational study on 2257 subjects also reported lower mean difference of $8.97 \mathrm{~mL} / \mathrm{min} / 1.73 \mathrm{~m}^{2}$ using BIS $1{ }^{20}$. Fan et al. showed no superiority to CKD EPI equation compared with other equations (Japanese, BIS, and Caucasian and Asian pediatric and adult subjects (CAPA) equation) ${ }^{21}$. On the other hand, some other authors did not find advantage of using BIS1 in the elderly ${ }^{21,22,23}$. Diagnostic performance of four different creatinine-based eGFR equations did not give an advantage to any of the equations including BIS1 in the elderly ${ }^{22}$. Finally, David-Neto et al. evaluated four equations (MDRD4, CKD EPI, BIS1, and modified Cockcroft-Gault equation) in elderly renal-transplanted recipients and concluded that CKD EPI equation was superior with the lowest bias and better accuracy ${ }^{23}$. It is acknowledged that decline in eGFR value in the elderly subjects does not necessarily equal CKD. HUGE equation was proposed as a possible tool in distinguishing normal aging from CKD ${ }^{15,24,25}$. In our group of elderly, CKD prevalence was significantly lower regardless which equation was used when we included HUGE equation in analyses. However, we observed less falsely diagnosed CKD or in another words we observed more normal-aging when BIS1 was used instead of CKD EPI. Our study has several limitations. First, we determined eGFR only once, therefore we cannot claim with certainty about an existence of chronic condition or CKD. In addition, our study included subjects from only a part of the rural areas of continental Croatia. Nevertheless, the concordance of our results and the results of other multicentric studies and studies that included a larger number of subjects is of significant value.

In conclusion, we found eGFR to be $8 \mathrm{ml} / \mathrm{min} / 1.73 \mathrm{~m}^{2}$ lower when using BIS1 equation compared to CKD EPI equation. Consecutively, the prevalence of CKD was higher with BIS1 than with CKD EPI equation i.e. CKD EPI underestimated CKD prevalence in elderly. Based on our results that are in agreement with most of other authors we could suggest that BIS1 equation is more suitable in distinguishing true CKD from normal aging than CKD EPI equation. Furthermore, more accurate diagnosis of $\mathrm{CKD}$, and better determination of $\mathrm{CKD}$ prevalence in subjects older than 70 years could be obtained using BIS1 equation with addition of HUGE equations eliminating in that way subjects with normal kidney aging.

\section{ACKNOWLEDGMENTS}

We are grateful to all the collaborators who participated in this research study and to all farmers who responded to the measurements. This study was supported by the grant Croatian Ministry of Science research project "Endemic Nephropathy in Croatia: Epidemiology, Diagnosis, Etiology" (108-0000000329). The authors have no conflicts of interest to declare. 
TAbles And Figures

Table 1. Demographic and clinical characteristics of study population

\begin{tabular}{|c|c|c|c|c|}
\hline & Whole group & Men & Women & $\mathrm{p}$ \\
\hline$\%,(\mathrm{n})$ & (383) & $35.51(136)$ & $64.49(247)$ & $<0.001$ \\
\hline Age, years & $75(72-78)$ & $74(71-78)$ & $75(73-79)$ & 0.063 \\
\hline Body weight, kg & $73(64-82)$ & $77(69-86)$ & $70(61-81)$ & $<0.001$ \\
\hline Body height, $\mathrm{cm}$ & $160.5(155.0-170.0)$ & $171(167.0-175.0)$ & $157(153.3-161.0)$ & $<0.001$ \\
\hline BMI, $\mathrm{kg} / \mathrm{m}^{2}$ & $27.6(24.6-30.9)$ & $26.5(23.7-28.9)$ & $28.5(25.0-32.0)$ & $<0.001$ \\
\hline BMI <25, \% (n) & $37.6(144)$ & $41.2(56)$ & $35.6(88)$ & \multirow{3}{*}{$<0.001$} \\
\hline \multirow{2}{*}{$\begin{array}{l}\text { BMI 25-30, \% (n) } \\
\text { BMI } \geq 30, \%(n)\end{array}$} & $36.3(139)$ & $44.9(61)$ & $31.6(78)$ & \\
\hline & $26.1(100)$ & $13.9(19)$ & $32.8(81)$ & \\
\hline BSA (Moesteller) m² & $1.82(1.68-1.96)$ & $1.90(1.79-2.03)$ & $1.76(1.62-1.90)$ & $<0.001$ \\
\hline WC, cm & $98.7 \pm 13.2$ & $99.7 \pm 11.7$ & $98.1 \pm 13.9$ & 0.392 \\
\hline Abdominal obesity, $\%$ & $38.1(146)$ & $24.3(33)$ & $45.7(113)$ & $<0.001$ \\
\hline Systolic blood pressure, $\mathrm{mmHg}$ & $156.4 \pm 25.6$ & $154.0 \pm 23.5$ & $157.4 \pm 26.7$ & 0.324 \\
\hline Diastolic blood pressure, $\mathrm{mmHg}$ & $85.4 \pm 14.1$ & $83.0 \pm 13.5$ & $86.7 \pm 14.4$ & 0.053 \\
\hline Hypertension, \% & $89.0(341)$ & $83.1(113)$ & $92.3(228)$ & 0.009 \\
\hline Diabetes, \% & $18.0(69)$ & $16.9(23)$ & $18.6(46)$ & 0.613 \\
\hline Current smokers, \% & $7.05(27)$ & $15.44(21)$ & $2.43(6)$ & \multirow{2}{*}{0.120} \\
\hline & $12.53(48)$ & $31.62(43)$ & $2.02(5)$ & \\
\hline Fasting blood glucose, $\mathrm{mmol} / \mathrm{L}$ & $5.6(5.1-6.6)$ & $5.6(5.0-6.6)$ & $5.6(5.2-6.7)$ & 0.816 \\
\hline Total cholesterol, $\mathrm{mmol} / \mathrm{L}$ & $5.8(5.0-6.6)$ & $5.4(4.9-6.3)$ & $6.0(5.1-6.9)$ & 0.002 \\
\hline HDL cholesterol, mmol/L & $1.53(1.29-1.85)$ & $1.43(1.22-1.76)$ & $1.55(1.33-1.92)$ & 0.049 \\
\hline LDL cholesterol, mmol/L & $3.5(2.9-4.2)$ & $3.3(2.7-4.0)$ & $3.6(2.9-4.4)$ & 0.063 \\
\hline Triglycerides, $\mathrm{mmol} / \mathrm{L}$ & $1.4(1.1-1.9)$ & $1.2(0.9-1.8)$ & $1.6(1.2-2.2)$ & $<0.001$ \\
\hline Serum creatinine, $\mu \mathrm{mol} / \mathrm{L}$ & $82(72-99)$ & $94(84-107)$ & $76(69-91)$ & $<0.001$ \\
\hline eGFR CKD EPI equation & $66.8(55.7-76.5)$ & $68.5(57.4-79.0)$ & $65.7(53.8-74.2)$ & 0.025 \\
\hline eGFR BIS1 equation & $58.2(49.9-64.2)$ & $58.7(51.5-65.9)$ & $57.0(49.1-63.2)$ & 0.032 \\
\hline HUGE equation & $-1.62(-2.9-8.4)$ & $9.3(8.3-9.7)$ & $-2.5(-4.1-(-1.6))$ & $<0.001$ \\
\hline ACR mg/g & $9.4(5.4-24.6)$ & $8.6(4.4-35.2)$ & $9.6(5.6-22.1)$ & 0.523 \\
\hline Albuminuria, \% (ACR> 30) & $14.9(57)$ & $17.6(24)$ & $13.4(33)$ & 0.236 \\
\hline
\end{tabular}

$\mathrm{BMI}$ = body mass index; $\mathrm{BSA}=$ body surface area; $\mathrm{WC}=$ waist circumference; $\mathrm{eGFR}=$ estimated glomerular filtration rate; $\mathrm{ACR}=$ albumin-to-creatinine ratio 
Table 2. Prevalence of chronic kidney disease defined as eGFR $<60 \mathrm{~mL} / \mathrm{min} / 1.73 \mathrm{~m}^{2}$

\begin{tabular}{|c|c|c|c|c|c|c|}
\hline & \multicolumn{2}{|c|}{ Whole group } & \multicolumn{2}{|c|}{ Men } & \multicolumn{2}{|c|}{ Women } \\
\hline $\mathrm{N}$ & \multicolumn{2}{|c|}{383} & \multicolumn{2}{|c|}{136} & \multicolumn{2}{|c|}{247} \\
\hline & CKD EPI & BIS1 & CKD EPI & BIS1 & CKD EPI & BIS 1 \\
\hline \multirow[t]{2}{*}{ CKD prevalence, \% } & 34.72 & 57.4 & 30.9 & 52.9 & 36.8 & 59.9 \\
\hline & $\%(\mathrm{n})$ & $\%(\mathrm{n})$ & $\%(\mathrm{n})$ & $\%(\mathrm{n})$ & $\%(\mathrm{n})$ & $\%(\mathrm{n})$ \\
\hline $\begin{array}{c}\text { Stage } 1 \\
\text { eGFR } \geq 90\end{array}$ & $1.6(6)$ & $0.3(1)$ & $3.7(5)$ & 0 & $0.4(1)$ & $0.4(1)$ \\
\hline $\begin{array}{c}\text { Stage } 2 \\
\text { eGFR= 60-89 }\end{array}$ & $63.7(244)$ & $42.3(162)$ & $65.4(89)$ & $47.1(64)$ & $62.8(155)$ & $39.7(98)$ \\
\hline $\begin{array}{l}\text { Stage stage } 3 \mathrm{~A} \\
\mathrm{eGFR}=45-59\end{array}$ & $21.1(81)$ & $41.0(157)$ & $22.1(30)$ & $39.7(54)$ & $20.6(51)$ & $41.7(103)$ \\
\hline $\begin{array}{l}\text { Stage stage 3B } \\
\text { eGFR }=30-44\end{array}$ & $10.2(39)$ & $13.8(53)$ & $4.4(6)$ & $9.6(13)$ & $13.4(33)$ & $16.2(40)$ \\
\hline $\begin{array}{c}\text { Stage } 4 \\
\text { eGFR=15-29 }\end{array}$ & $2.9(11)$ & $2.1(8)$ & $3.7(5)$ & $2.9(4)$ & $2.4(6)$ & $1.6(4)$ \\
\hline $\begin{array}{c}\text { Stage } 5 \\
\text { eGFR } \leq 15\end{array}$ & $0.52(2)$ & $0.52(2)$ & $0.7(1)$ & $0.7(1)$ & $0.4(1)$ & $0.4(1)$ \\
\hline P value & & & & & & \\
\hline
\end{tabular}

eGFR = estimated glomerular filtration rate $\left(\mathrm{mL} / \mathrm{min} / 1.73 \mathrm{~m}^{2}\right) ; \mathrm{CKD}=$ chronic kidney disease

Table 3. Prevalence of chronic kidney disease defined as eGFR $<60 \mathrm{~mL} / \mathrm{min} / 1.73 \mathrm{~m}^{2}$

In whole group

\begin{tabular}{|c|c|c|c|}
\hline & \multicolumn{2}{|c|}{ CKD EPI } & Total \\
\hline BIS1 & $\geq 60, \%(\mathrm{n})$ & $<60, \%(\mathrm{n})$ & $42.6(163)$ \\
\hline$\geq 60, \%(\mathrm{n})$ & $42.5(163)$ & $0(0)$ & $57.4(220)$ \\
\hline$<60, \%(\mathrm{n})$ & $22.7(87)$ & $34.7(133)$ & 383 \\
\hline Total, \% (n) & $65.2(250)$ & $34.7(133)$ & $<0.001$ \\
\hline P value & \multicolumn{3}{|c}{} \\
\hline
\end{tabular}

Kappa: 0.56 (95\% CI 0.49-0.63) 


\begin{tabular}{|c|c|c|c|c|c|}
\hline \multirow[t]{2}{*}{$\mathrm{eGFR}<60 \mathrm{~mL} / \mathrm{min} / 1.73 \mathrm{~m}^{2}$} & \multicolumn{2}{|c|}{$\begin{array}{l}\text { BIS } 1 \\
\mathrm{~N}=46\end{array}$} & \multicolumn{2}{|c|}{$\begin{array}{l}\text { CKD EPI } \\
\qquad \mathrm{N}=23\end{array}$} & \multirow[t]{2}{*}{ P value } \\
\hline & HUGE $<0$ & HUGE $\geq 0$ & HUGE $<0$ & HUGE $\geq 0$ & \\
\hline Stage 3a, \% (n) & $37.0(17)$ & $26.1(12)$ & $26.1(6)$ & $8.7(2)$ & \multirow{5}{*}{0.465} \\
\hline Stage $3 b, \%(n)$ & $17.4(8)$ & $4.3(2)$ & $26.1(6)$ & $8.7(2)$ & \\
\hline Stage 4, \% (n) & $8.7(4)$ & $4.3(2)$ & $17.4(4)$ & $8.7(2)$ & \\
\hline Stage $5, \%(\mathrm{n})$ & $2.2(1)$ & 0 & $4.3(1)$ & 0 & \\
\hline Total, \% (n) & $65.3(30)$ & 34.7 (16) & 73.9 (17) & $26.1(6)$ & \\
\hline
\end{tabular}

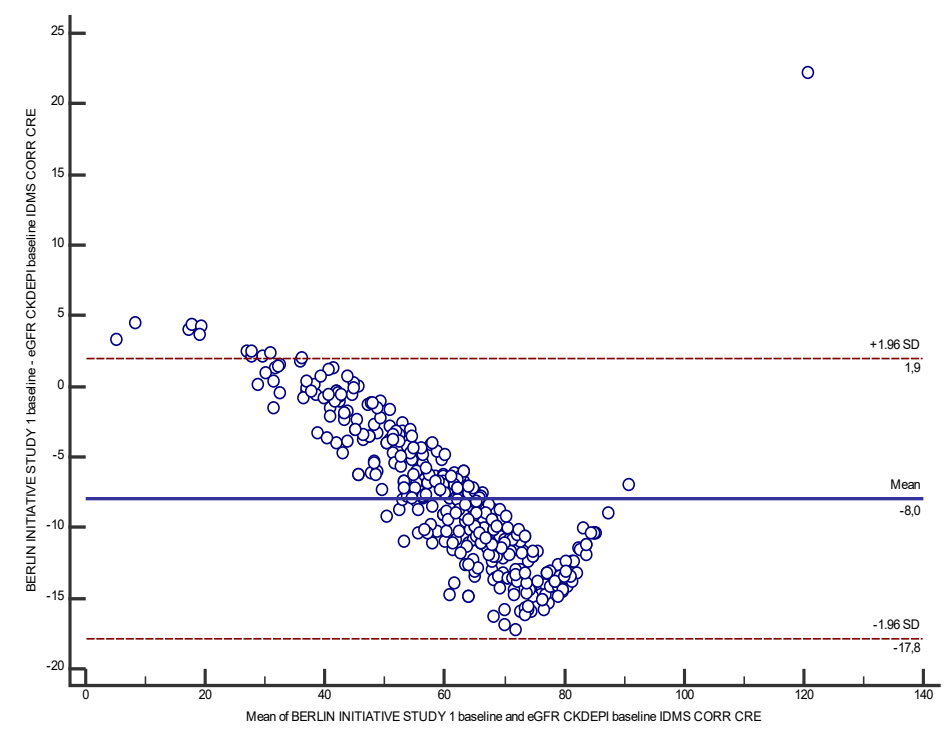

Figure 1. Bland-Altman plots of the estimated filtration rate (eGFR) as obtained CKD EPI against obtained BIS1 equation for the subjects older than 70 years The horizontal median continuous line represents the bias, and the dotted horizontal lines represent the upper and lower limits of agreement. BIS1 = Berlin Initiative Study; CKD EPI = Chronic Kidney Disease Epidemiology Collaboration

\section{REFERENCES:}

1. GBD Chronic Kidney Disease Collaboration. Global, regional, and national burden of chronic kidney disease, 1990-2017: a systematic analysis for the Global Burden of Disease Study 2017. Lancet. 2020;395:709-33.

2. Mills KT, Xu Y, Zhang W, Bundy JD, Chen CS, Kelly TN, et al. A systematic analysis of worldwide population-based data on the global burden of chronic kidney disease in 2010 . Kidney Int. 2015;88:950-7.
3. Tonelli M, Pfeffer MA. Kidney disease and cardiovascular risk. Annu Rev Med. 2007;58:123-39.

4. Gansevoort RT, Correa-Rotter R, Hemmelgarn BR, Jafar TH, Lambers Heerspink HJ, Mann JF, et al. Chronic kidney disease and cardiovascular risk: epidemiology, mechanisms, and prevention. Lancet. 2013;382:339-52.

5. Astor BC, Matsushita K, Gansevoort RT, Van der Velde M, Woodward M, Levey AS, et al. Lower estimated glomerular 
filtration rate and higher albuminuria are associated with mortality and endstage renal disease: A collaborative metaanalysis of kidney disease population cohorts. Kidney Int. 2011;79:1331-40.

6. Benghanem Gharbi M, Elseviers M, Zamd M, Belghiti Alaoui A, Benahadi N, Trabelssi EH, et al. Chronic kidney disease, hypertension, diabetes, and obesity in the adult population of Morocco: how to avoid "over"- and "under"diagnosis of CKD. Kidney Int. 2016;89:1363-71.

7. Ebert N, Jakob O, Gaedeke J, Van Der Giet M, Kuhlmann MK, Martus P, et al. Prevalence of reduced kidney function and albuminuria in older adults: the Berlin Initiative Study. Nephrol Dial Transplant. 2017;32:997-1005.

8. Go A, Chertow G, Fan D, McCulloch Ch, Hsu Chi. Chronic Kidney Disease and the Risks of Death, Cardiovascular Events, and Hospitalization. N Engl J Med. 2004;351:1296-305.

9. Stevens PE, Levin A, Kidney Disease: Improving Global Outcomes Chronic Kidney Disease Guideline Development Work Group Members. Evaluation and management of chronic kidney disease: synopsis of the kidney disease: improving global outcomes 2012 clinical practice guideline. Ann Intern Med. 2013;158:825-30.

10. Levey AS, Stevens LA, Schmid CH, Zhang YL, Castro AF 3rd, Feldman HI, et al. A new equation to estimate glomerular filtration rate. Ann Intern Med. 2009;150:604-12.

11. Schaeffner ES, Ebert N, Delanaye P, Frei U, Gaedeke J, Jakob $\mathrm{O}$, et al. Two novel equations to estimate kidney function in persons aged 70 years or older. Ann Intern Med. 2012;157:471-81.

12. Denic A, Mathew J, Lerman LO, Lieske JC, Larson JJ, Alexander MP, et al. Single-nephron glomerular filtration rate in healthy adults. N Engl J Med. 2017;376:2349-57.

13. Denic A, Ricaurte L, Lopez CL, Narasimhan R, Lerman LO, Lieske JC, et al. Glomerular volume and glomerulosclerosis at different depths within the human kidney. J Am Soc Nephrol. 2019;30:1471-80.

14. Denic A, Lieske JC, Chakkera HA, Poggio ED, Alexander MP, Singh P, et al. The substantial loss of nephrons in healthy human kidneys with aging. J Am Soc Nephrol. 2017;28:313-20.

15. Alvarez-Gregori JA, Robles NR, Mena C, Ardanuy R, Jauregui R, Macas-Nu Nunez JF. The value of a formula including haematocrit, blood urea and gender (HUGE) as a screening test for chronic renal insufficiency. J Nutr Health Aging. 2011;15:480-4.

16. Koppe L, Klich A, Dubourg L, Ecochard R, Hadj-Aissa A. Performance of creatinine-based equations compared in older patients. J Nephrol. 2013;26:716-23.
17. Lengnan X, Aiqun C, Ying S, Chuanbao L, Yonghui M. The effects of aging on the renal function of a healthy population in Beijing and an evaluation of a range of estimation equations for glomerular filtration rate. Aging (Albany NY). 2012;13:6904-17.

18. Polkinghorne KR, Wolfe R, Jachno KM, Wetmore JB, Woods RL, McNeil JJ, et al. ASPREE Investigator Group. Prevalence of chronic kidney disease in the elderly using the ASPirin in Reducing Events in the Elderly study cohort. Nephrology (Carlton). 2019;24:1248-56.

19. Tarantini L, McAlister FA, Barbati G, Ezekowitz JA, Cioffi G, Faggiano P, et al. Chronic kidney disease and prognosis in elderly patients with cardiovascular disease: Comparison between CKD-EPI and Berlin Initiative Study-1 formulas. Eur J Prev Cardiol. 2016;23:1504-13.

20. Corsonello A, Roller-Wirnsberger R, Wirnsberger G, Ärnlöv J, Carlsson AC, Tap L, et al. Clinical Implications of Estimating Glomerular Filtration Rate with Three Different Equations Among Older People. Preliminary Results of the Project «Screening for Chronic Kidney Disease among Older People across Europe (SCOPE)». J Clin Med. 2020;9:294.

21. Fan L, Levey AS, Gudnason V, Eiriksdottir G, Andresdottir $\mathrm{MB}$, Gudmundsdottir $\mathrm{H}$ et al. Comparing GFR estimating equations using cystatin $\mathrm{C}$ and creatinine in elderly individuals. J Am Soc Nephrol. 2015;26:1982-9.

22. Da Silva Selistre L, Rech DL, De Souza V, Iwaz J, Lemoine S, Dubourg L. Diagnostic Performance of CreatinineBased Equations for Estimating Glomerular Filtration Rate in Adults 65 Years and Older. JAMA Intern Med. 2019;179:796-804.

23. David-Neto E, Kamada Triboni AH, Ramos F, Agena F, Galante NZ, Altona M, et al. Evaluation of MDRD4, CKD-EPI, BIS-1, and modified Cockcroft-Gault equations to estimate glomerular filtration rate in the elderly renaltransplanted recipients. Clin Transplant. 2016;30:1558-63.

24. Robles NR, Felix FJ, Lozano L, Miranda I, FernandezBerges D, Macías JF. The H.U.G.E. Formula (Hematocrit, Urea, Sex) for Screening Chronic Kidney Disease (CKD) in an Age-Stratified General Population. J Nutr Health Aging. 2015;19:688-92.

25. Musso CG, de Los Rios E, Vilas M, Terrasa S, Bratti G, Varela F, et al. The HUGE formula (hematocrit, urea, gender) for screening for chronic kidney disease in elderly patients: a study of diagnostic accuracy. Int Urol Nephrol. 2017;49:677-680. 